\title{
Solidary Economy. Cooperative Modernization of Russia (1907-1914)
}

\author{
Lubkov Alexey Vladimirovich \\ Rector of the Moscow Pedagogical State University \\ Doctor of Historical Sciences, Professor \\ Corresponding member of Russian Academy of Education \\ 119991, Russia, Moscow, Malaya Pirogovskaya street, building 1
}

\begin{abstract}
Cooperative movement in Russia in the late 19th and early 20th century emerges as a unique socio-cultural phenomenon that had economic, cultural enlightenment and educational importance. It provides an original model of modernisation development, demonstrating, vividly and explicitly, the complexity and multidimensional nature of Russia's modernisation process. Cooperation was of enormous educational importance, reforming Russian people's way of life and cultivating spiritual values. Practical implications of inquiry into the role and experience of the Russian cooperation lie in opportunities offered for contemplation of Russia's cultural self-identification issues, current economic objectives and public life, both at a regional level and countrywide.
\end{abstract}

Keywords: cooperation, modernization, personality, solidary society, context, vertical and horizontal public relations, human activity, values and meanings.

\section{Introduction}

Cooperation in the late 19th and early 20th century Russia is seen as a major modernisation element, with the view to interaction of multiple factors, including institutional structures, socio-political and cultural background, values and ideals and activities of an individual. In the context of history, theorists and practitioners of cooperation explored the very nature of a union or co-existence of people, communities, civilisations, essential elements and mechanism of functioning of a solidary society the arrival at which remains an important idea in Russia today in connection with continued inquiry into approaches to and strategies of Russia's civilisation development. Russian cooperation was based on traditional meanings and values and accumulated culturally unique features while also embodying progressive elements of the development of the society in its economic, social and political aspects.

\section{Methodology}

Currently, a prominent feature of the science of history involves a reflection on anthropologic parameters of social development, its laws and specific features. The anthropology perspective makes it possible to comprehend deep manifestations of the human phenomenon, its place and role in the development of sociocultural processes. The discourse of anthropocentrism and the inquiry into human activity as a factor of modernisation further enhances our understanding of the man's civil and social stance.

\section{Institutional bases}

The study of documents located in the collections of five Russian archives, including state archives of Kostroma, Ivanono, Ryazan, Tula regions and Moscow's Central Historical Archives. The large corpus of printed sources and press reports allow us to trace the emergence of the cooperative movement in Russia and major directions of its development, with the central provinces of the Russian Empire serving as a representative sample. That is of major importance because not only it raises researchers' awareness as to the sphere of economic and socio-cultural history, but also because it helps establish conceptual patterns of functioning of a solidary form of economy the process of fulfilling a range of nationwide objectives.

In pre-World War I period, credit cooperation in Central Russia had embarked on a path of self-determination and defined itself on quite a large scale as an economic organisation. The degree of people's trust in cooperation was sufficiently high, the fact testified to by a big rise in deposit and loans operations. Loans cooperatives helped peasants to organise their economies on a sound financial basis. Although the share of cooperative funds in the overall volume of transaction of peasant households was one fifth at its highest, cooperation had been rising in prominence as a factor of transformation of the Russian countryside. 
Due to the development of credit cooperation approximately 5 bin roubles were invested into agriculture and crafts in the five years preceding World War I. [Korelin A. P. Kooperatsiya I kooperativnoedvizheniye v Rossii, 1860-1917 gg. Moscow, 2009, p. 369.] This provided much needed support to peasant households during the difficult period of Stolypin reforms and benefited agricultural and agrotechnical modernisation of the most enterprising elements of the countryside.

Credit cooperation, while enjoying most of the success, gave rise to other types of cooperatives, including consumers' societies, agricultural artels, tovarishhestvoetc. The development of social links of a new type and new means of selfexpression exemplified by cooperative institutions and ideology laid the foundations for the establishment of solidary economy in Russia at the turn of the 20th century.

Russia occupied the first place worldwide in terms of cooperative movement development, a number of cooperative societies and their members. Economists estimate that 16-18 million and up to 23-24 million people were involved in cooperation by the beginning of 1917, which, if their families are included in the calculation, comprises $2 / 3$ of economically active population. Researchers emphasise the difficulty of estimating precisely the share of the Russian Empire's population involved in cooperation because some members belonged to either several types of cooperatives or several unions of a single type. If we include family members in the estimate, nearly half of Russia's population (estimated to be 171,900,000 as of January 1st 1913 [The figure serves as a starting point for calculation according to the data used at the All-Russia Exhibition held in Kiev in 1913. Cf.: KooperatsiyanaVserossiyskoivystavke v Kieve v 1913 g. Kiev, 1914; Farutin A. I., "Kharakter I ossobennostikooperativnogodvizheniya v dorevolyutsionnoiRossii, in UchyonyezapiskiKaliningradskogouniversiteta, vol. 4. Kaliningrad, 1970, p. 62.] was involved in the activities of various cooperative types.

The individual or personality dimension of the modernisation discourse in the Russian cooperative movement took the form of predominantly peasant entrepreneurial initiatives that were self-directed and took place on a large scale. Peasants' active participation in artel-based production made it possible to increase animal farming productivity, making it profitable and competitive. A certain trend had emerged - the cooperatives were usually created and led by the more affluent strata of the rural population.

The experience of cooperative development shows a path allowing for harmonisation of interests, both personal and public, in a multilayered society with plenty of specialised roles and strong differentiation.

\section{Context}

Focusing on the heterogeneous context of Russian Empire in the late 19th and early 20th century, we can discern the logic of horizontal networking relationships and vertical connections, interaction of interlinked processes and coordination of a variety of practices and forms of public initiative. Russian cooperation served as an important tool in imperial discourse.

The amplitude of the relations between the authorities and the society, as exemplified by the experience of their interactions pertaining to the cooperatives, demonstrates the options enabling to overcome social conflicts and society antagonisms in a peaceful manner in the ongoing process of modernisation.

The cooperation in Russia offered solutions to major objectives of public regulation of the economy from below supplementing substantially the government's attempts to regulate the economy along administrative and legal lines. The combination of both of these factors brought about new positive advances in the structure of Russian economy.

The part the state was to play in the cooperative movement was not limited to financial support only. The state, in the process of agrarian change, saw cooperation as one of the basic mechanisms of the reforms and attempted to secure support for the measures introduced by the government at a grass root level, among peasants. Having said that, the measures introduced by the authorities were quite moderate. In the period before World War I, the government's task was not to artificially stimulate the work of the cooperatives, which were sufficiently active anyway, but rather to make sure it is contained within the framework, that was defined by the authorities themselves, taking into account the maturity of the entire movement, including political aspects, i.e. its loyalty to the existing political regime.

World War I unveiled population-wide potential of cooperation and national importance of cooperative economic activities. Cooperative activists were the first to propose the programme aimed at a modernisation of the economy and involvement of the entire Russian society. The programme attached special importance to unifying and coordinating the endeavour of the government, zemstvo, public and private organisations in the war effort and ensuring that the activities underway are well-planned. Implementing defence contracts, which included preparation and sale of dried vegetables, producing army underwear or uniform, the Russian cooperation demonstrated its importance as a genuine force of the economy capable of dealing with major tasks under difficult circumstances. Army supplies had an important impact on the entire cooperative movement. 
First, they contributed to a wide proliferation of intermediary operations in cooperation. Second, they led to a growth of cooperative unions. The extent of intermediary operations and the cooperative unification trend may be seen as two sides of a single process of intensive development of cooperation in Russia.

The experience of Russian cooperative movement bears witness to the need of any kind of public activity of selfimposed limits both in the economic sphere and the sphere of politics. For example, the cooperation in Russia proved to be unable to undertake responsibility for production and distribution on a national scale. The attempts to assert cooperation's monopoly position on the goods and services market could have had dire consequences for the economy. Similarly, devastating effects could have resulted from its complete merger with the state apparatus or from its subjugation to liberal waves of private enterprise.

The cooperation in Russia proved to be an important feedback channe in the interaction hierarchy of the multi-agent system of the society and the authorities, showing the principles on which well-balanced positive relationship could be built.

Self-organisation and self-determination of the Russian cooperation had not emerged per se. Rather, it was an outcome of prolonged multifarious focused endeavor of zemstvo as a unique institute of local self-government, and also that of the state authorities perceiving the opportunities offered by cooperation in bringing about peaceful transformation of the Russian society.

Socio-political and socio-cultural context can be viewed from a specific vantage point allowing to analyse not only the transformation taking place in the social environment but also personal changes that occur in the transformation aftermath. The cooperation discourse was able to unite the cooperative members energy aimed at modernisation with the social power of the peasant mir.

\section{Values and meanings}

Axiological factor of modernisation process has currently assumed special importance. The study of axiological element of the cooperative movement in Russia allows to define a hierarchy of core values. It is possible, by analysing the ideology of cooperation and theoretical heritage left by cooperation activists to find solutions to the question of the spiritual and the material in a human being, a hidden potential for genuine creativity of the masses and personal selfactualisation, a balance of liberty and responsibility, individualism and conciliar consciousness, constitutionalism and solidarity.

Cooperation, although a phenomenon of pan-European culture, developed on Russian soil under the impact of national (including regional) features. Civilisation identity, seen from that standpoint, emerges as a distinctive development resource.

Apology of individualism was alien to century-old concepts of commune, or artel, or mir-based labour. The idea of cooperation, on the contrary, struck a deep chord in people's consciousness. A cooperative is a voluntary union of economic entities that primarily pursue material profit resulting from joint work. An economic model that is principally different from capitalism, cooperation naturally brought together the Christian tradition of human unity or brotherhood with the concept of personal liberty and self-esteem. Strategic objectives of cooperation blended with issues of socioeconomic, political and spiritual development of the Russian society.

From their inception, the ideas of cooperation were closely knit with aspirations for free collective labour based on selfregulation principles. They aimed at developing the individual's desire for labour leading not only to personal enrichment but also to the common good and welfare of the society. Cooperation theorists were convinced that cooperative labour was capable of bringing people to a higher level of organisation and ethical values. The experience of cooperation reaffirmed its important feature that was in contrast with other labour forms - cooperation was capable of facilitating production but also enriching spiritual lives of cooperative members.

The Russian cooperation far extended the boundaries of finance and credit or trading and procurement or other enterprises that were part of its organisational structure. It came to realise a common cultural mission by reforming the entire way of life of the Russian people. The educational and enlightenment factor in the cultural mission of cooperation proves that further modernisation is but impossible without personal self-change.

\section{Humanactivity}

Prominent Russian cooperation theorists developed projects aimed at preservation and development of Russian traditions. These profound and responsible writers offered to public conciseness a dissenting view of the Russian modernisation phenomenon, leaving behind the concept of Russia as an 'underdeveloped' country', a 'second-tire country of economic catch-up'. Modernisation is perceived not as a linear process of a comprehensive 'westernisation' of the country or its transformation along certain 'progressive' lines. 
They studied Russian national culture, its unique features they made appeals to Russian mentality, to genuine Russian traditions that had, for many centuries, accumulated the collectivist experience. Cooperation theorists and practitioners emphasised the need to contemplate goals and motivation, meaning and consequences of the moral choice of the man, cultivating his soul and individuality. Reflection on this issue remains meaningful in the current standoff between ideologies and outlooks across the world, the prevailing moral crisis.

Russian social and philosophical thought created the tradition according to which the state and the civil society had seen the institutional unity of law, religion and family. The concepts laid down by Russian thinkers included the ideas that would later be developed by researchers looking into civil society issues. They were able to demonstrate, for instance, that the very logic of civil society suggests the existence of such social links that bring together the family and other voluntary unions aimed at public welfare. In the focus of public welfare there stands the man as an individual and citizen who takes decisions and accepts responsibility.

It is important to note that the model of civil society was in accord with Russian peasant mentality that was raised on the ideas of communal life (obshchinnost'), solidarity, and consonance. Spiritual and moral values of public life and religious institutions were important integrating factors of social practices that lay at the core of Russian cooperative movement.

\section{Conclusion}

Interaction between diverse institutional structures, cultural context and individual activity of the human being allows us to conclude that there emerged an effect of natural national synthesis capable to respond to the challenges of the time. It is on this synthesis that the fate of ongoing and discrete Russian modernisation depends.

Cooperation as a solidary economy model was characterised by the existence of multi-agent subject-object relationships that were defined by a combination of personal and public interests, a well-balanced system of vertical hierarchy and horizontal structures with the predominating role of positive feedback in the interaction dynamics.

Diverse practice of cooperation shows that there emerged a mechanism of economy that was most suitable to the national concept of the essence of labour and moral canons of Orthodox Christianity with its faith in spiritual brotherhood of the humanity and triumph of justice. The Russian cooperation, being a sufficiently in-depth reflection of religious and ethical outlook of the Russian people, its image of the existence and a human collective, the nature of labour, economy and culture, became a sort of a practical application of those principles. Owing largely to that circumstance cooperation activists were able to provide fertile soil for people's self-directed enterprise, creative initiative and energy, tapping into internal sources of social creativity, thus bearing rich fruit and bringing about blossoming of the cooperative movement in Russia.

Inquiry into the experience of the Russian cooperative movement in the late 19th and early 20th century stimulates the search for concrete ways of national and governmental, spiritual, and socio-economic development, contemplation on the groundwork lack of which deprives societies of their stability and core meanings. It is the task of contemporary society to bring about the formation of a solidary society that is based on core spiritual and moral values and norms of Christian ethics.

\section{References}

State archive of the Kostroma region. Fund 208. Inventory. 1. Case 1185, 1241; 2103. Fund. 133. Inventory 2. Archiving. 1434.

State archive of the Ivanovo region. Fund. R-1377. Inventory 1. Archiving. 88.

State archive of Tula region. Fund 11. Inventory. 1. Archiving.606.

State archive of the Ryazan region. Fund 899. Inventory 1. Archiving. 2.

Central historical archive of Moscow. Fund. 326. Inventory. 1. Archiving. 828, 845. Fund. 419. Inventory. 1. Archiving. 3202 .

Vestnikcooperation. 1911. №6; 1912. №. 5; 1914. № 1, № 2, № 9; 1915. № 1, № 2, № 8; 1916. №. 6; 1917. № 2-3, № 9-10.

Vestnikkooperativnyhsoyuzov. 1915. № 1, № 3.

Vestnikagriculture. 1910. №6, № 7, № 10, № 11; 1912. № 22, № 41, № 45; 1913. № 1, № 5, № 10, № 11, № 44 ; 1914. № 4, № 20; 1915. № 7, № 16, № 44; 1916. № 28 .

The first All-Russian congress of representatives of cooperative institutions in Moscow on April 16-21, 1908. Works. M., 1908.

The second All-Russian congress of cooperation in Kiev on August 1-7, 1913. Works, Kiev.1915. 
Izvestiya of the Kostroma provincial zemstvo. № 5, № 6, № 8, № 11, № 12; 1915. № 1, № 3, № 4, № 5, № 6, № 9, № 11, № 12; 1916. № 1 .

Cooperative life. 1914. № 1; № 2, № 4, № 5, № 6, № 24; 1915. № 2, 17-18; 1916. № 2; № 7; 1918 . № 1 .

Moscow provincial zemstvo. Materials in cooperation in the Moscow province. Issue. 1915. XII,. XIII.

Soyuz potrebitelej. 1914. № 1, № 5; № 10-11; 1915. № 29.

Tver provincial territorial justice. Agronomical department. Works of the 1st Meeting of representatives of institutions of the small credit of the Tver province on August 20-22, 1913 Tver, 1913.

Tula provincial territorial justice. Magazine of a meeting of representatives of cooperatives of the Tula province on November 10-13, 1913 Tula, 1914.

Yaroslavl provincial zemstvo. Agronomical department. The report on butter artels of the Yaroslavl province for 1911 operational year. Yaroslavl, 1913. Economic department. Index of the cooperative organizations and agricultural societies of the Yaroslavl province. Yaroslavl, 1912. Works of the first congress of representatives of cooperative institutions of the Yaroslavl province (on January 22-26, 1913). Yaroslavl, 1913.

Averyanov V.V., VenediktovV.Yu., Kozlov A.V. Artel and collective person / Editor-in-chiefO.A. Platonov. Moscow, 2014.

Alekseev V.V. Modernization and revolution in Russia: synonyms or antipodes? // Industrial heritage: collection of materials of the International scientific conference. Saransk, on June 23-25, 2005. / Editor-in-chiefV.A. Vinogradov, N.M. Arsentyev. Saransk, 2005. Page 27-33.

Current problems of national history. The collection of scientific works / Under E.Yu. Bolotova, A.V. Lipatov, T.N. Oreshkina's edition. Moscow, 2017. 304 pages.

Bespalov S.V. Problems of social and economic modernization of pre-revolutionary Russia in a modern western historiography (Review)//History of Russia in modern foreign science. The collection of reviews and papers / Editor-in-chiefV.M. Shevyrin. Vol.1. Moscow, 2010. Page 153-192.

Bulgakov S.N. Heroism and self-sacrifice. From reflections about the religious nature of Russian intelligentsia//Vekhi. Collection of articles about Russian intelligentsia. Moscow, 1990. Page 29-75.

Bulgakov S.N. Philosophy of economy// Compositions in 2 vol. Vol. 1. Moscow, 1993. 603 pages.

Civil identity of the Russian intellectuals at the end of XIX - the beginning of the 20th centuries Sb. article / Editor-inchiefof N.A. Proskuryakov. Moscow, 2013. 290 pages.

DoykovYu.V.A.A. Evdokimov. The fate of the prophet in Russia. SPb., 1999. 192 pages.

Evdokimov A.A. Spiritual beauty of cooperation// Soyuz potrebitelej. 1917. №. 5. Page 15-16.

Mikheyev D. (Evdokimov A.A.) Country kooperatizm. Article second // Bulletin of the cooperative unions. 1917. № 12.

Evdokimov A.A. Methods of development of lecturers with audience on local cooperative courses//the Organization of local cooperative courses. Moscow, 1917.

Evdokimov A.A. On the way to the higher country school// Bulletin of the cooperative unions. 1916. №. 10-11.

Evdokimov A.A. On the way to the higher country school Moscow, 1918. 86 pages.

Evdokimov A.A. Updating of culture. Moscow, 1917. 16 pages.

Egorov V.G., Zozulya O.A., Paleolog M.V. Domestic industries of the nonchernozem village of the second half of XIX - the beginning of the 20th centuries (on materials of the Moscow province). Moscow, 2011. 448 pages.

Ivanov A.V. Historical and theoretical problems of domestic cooperation of the first quarter of the XX century / Scientific edition. A.V. Lubkov. Blagoveshchensk, 2007. 148 pages.

Kondratyev N.D. To a question of differentiation of the village// The Chosen works. Moscow, 1993. Page 414-435.

Kondratyev N.D. To a question of differentiation of the village// The Chosen works. MoscowKorelin A.P. Cooperation and the cooperative movement in Russia 1860-1917. Moscow, 2009. 390 pages.

Kropotkin P.A. Mutual aid as evolution factor. Moscow, 2011. 256 pages.

Lubkov A.V. Cooperative modernization of Russia on the eve of the revolution of $1917 / /$ The Personality. Time. Education. Articles and performances. Moscow, 2017. Page 176-194.

Lubkov A.V. War. Revolution. Cooperation. Moscow, 1997.

Lubkov A.V. Spiritual bases of the Russian cooperation//Personality. Knowledge. Culture. Moscow, 2002. Page 323328.

Lubkov A.V. Cooperative model of updating of Russia: pre-revolutionary experience //Models of social development of Russia: projects and authors (the second half of the 19th century - the beginning of the 20th century)/ Moscow, 2006. Page 136-156.

Makarov N.P. Country economy and its evolution. Moscow, 1920. T. 1. 23 pages.

Makarov N.P. New cooperation in agriculture and kartofelekrakhmalny production//Collection of statistical data on the Kostroma province. Issue II. Kostroma, 1911. 6, 84, 14, XIV pages. 
Makarov N.P. Main questions of cooperative ideology (Sociological and ethical nature of cooperation)//Bulletin of the Moscow regional union of cooperative associations. 1919. No. 1. Page 1-8.

Telitsyn V.L., Kozlov E.N. Russian cooperation: that it was. Sketches. Moscow, 2009. 336 pages.

Totomiants V.F. Cooperation in Russia. Prague, 1922. 173 pages.

Totomiants V.F. Theory, history and practice of consumer cooperation. SPb., 1913. 360 pages.

Tougan-Baranovsky M.I. Social bases of cooperation. Moscow, 2010. 496 pages.

Tyukavkin V.G. Great Russian peasantry and Stolypin agrarian reform. Moscow, 2001. 302 pages.

Chayanov A.V. Russian lnovodstvo, linen market and linen cooperation. Moscow, 1918. 177 pages.

Chayanov A.V. Main ideas and methods of public agronomics. Moscow, 1914. 123 pages.

Chayanov A.V. Main ideas and forms of the organization of country cooperation. Moscow, 1919.

Chayanov A.V. Main ideas and forms of agricultural cooperation. Moscow, 1927.

Shchagin E.M. About experience and lessons of Stolypin agrarian reform // The Power and public organizations of Russia in the first third of the XX century. Collection of articles. Moscow, 1994. Page 40-64. 